Marquette University

e-Publications@Marquette

Social and Cultural Sciences Faculty Research and

Publications

Social and Cultural Sciences, Department of

$12-1-2005$

Space and Place in the Metropolis: Arabs and Muslims Seeking Safety

Louise Cainkar

Marquette University, Louise.Cainkar@mu.edu

Accepted version. City and Society, Vol. 17, No. 2 (December 2005): 181-209. DOI. (C 2005 WileyBlackwell. Used with permission.

The definitive version is available at www.blackwell-synergy.com 


\title{
Space and Place in the Metropolis: Arabs and Muslims Seeking Safety
}

\author{
Louise Cainkar \\ Social and Cultural Sciences, Marquette University \\ Milwaukee, WI
}

Organizing a photographic social history in a way that captures your viewers' imaginations and convinces them of your argument is fraught with challenges. ${ }^{1}$ One is limited by the photos one has to work with and their capacity to project larger themes. Some themes are difficult to portray visually because they concern protracted processes, such as racialization. Some actions were simply not caught on film, such as women wearing hijab (headscarves) being spit upon.

Additionally, many important side- and sub-stories must be left untold. This photo essay on the Arab Muslim community in Chicago attempts to cover one hundred years of urban life and more recent attempts to locate safe space. It speeds through some periods and slows down for others, although each period merits its own discussion. The essay reflects the author's view of the history one should consider to understand recent events. The perspective is sociological, ethnographic, and humanistic, and is grounded in twenty years of research and participation (albeit as a non-Arab, non-Muslim) in this community.

All photos by Louise Cainkar, except as indicated. Photos may not be used without permission.

City and Society, Vol 17, No. 2 (December 2005): pg. 181-209. DOI. This article is @ American Anthropological Association and permission has been granted for this version to appear in e-Publications@Marquette. American Anthropological Association does not grant permission for this article to be further copied/distributed or hosted elsewhere without the express permission from American Anthropological Association. 
NOT THE PUBLISHED VERSION; this is the author's final, peer-reviewed manuscript. The published version may be accessed by following the link in the citation at the bottom of the page.

Arab and Muslim communities have been part of the American social landscape for more than one hundred years, although they are often seen as newcomers. Despite their long history in the United States, Arabs and Muslims found safe space difficult to locate after the September 11, 2001 attacks on the United States. This physical insecurity came about because much of the American public held Arabs and Muslims collectively responsible for the attacks. Such an attribution signifies the presence of other social processes that facilitate conflating both groups and seeing them as monolithic. That is, instead of the 9/11 attackers being viewed as extremists or outliers, like for example Oklahoma City bomber Timothy McVeigh, they were seen by many as archetypes of global Arab/Muslim civilization, which had been represented for years as promoting values and beliefs that are in opposition to American values and possessing little internal variance. Consequently, the attacks perpetrated by some group members were seen as the attacks desired by all group members. ${ }^{2}$ For those who thought this way, the right of such persons to a place in American society was questionable. These views played out in hate crimes, verbal assaults, and property attacks against Arabs and Muslims, challenging their use of public space. The American flag, symbol of loyalty to the United Sates, was a common prop in the hands of persons who shouted "go back to your country" or "we want to kill you" at Arabs and Muslims, who were assumed to be inherently disloyal (although many of them were born in the United States).

Ethnographic research on the impacts of the 9/11 attacks on Arab Muslims in metropolitan Chicago shows that attacks on persons and property were more likely to occur in suburban space where Arab Muslims were a notable minority than in either the city or other suburbs; that women were almost twice as likely as men to be verbally and physically assaulted; and that women who wore hijab or were in the company of someone wearing hijab were the most likely to be attacked. ${ }^{3}$ These patterns make sense when they are understood in the context of larger social processes: the development of a racializing discourse that was widely embraced and allowed to mature partly because it never mentioned race, the attendant consequences of this discourse for rights in public space, and the broader movement of global Islamic revival.

All photos by Louise Cainkar, except as indicated. Photos may not be used without permission.

City and Society, Vol 17, No. 2 (December 2005): pg. 181-209. DOI. This article is @ American Anthropological Association and permission has been granted for this version to appear in e-Publications@Marquette. American Anthropological Association does not grant permission for this article to be further copied/distributed or hosted elsewhere without the express permission from American Anthropological Association. 
NOT THE PUBLISHED VERSION; this is the author's final, peer-reviewed manuscript. The published version may be accessed by following the link in the citation at the bottom of the page.

The concept of racialization is useful for capturing the sociohistorical process that promoted essentialized discourses about Arabs (and later Muslims), marketed dehumanizing representations of them, encouraged a public understanding that all group members think the same, and tied these assumptions to a messy but actionable phenotype, all of which resulted in a downgrading of the collective rights and social status of Arabs in the United States. ${ }^{4}$ In the early years of the Arab American experience (1890-1930), the social status of Arab Americans was largely similar to that of white ethnics, although in some places their rights as marginal whites were challenged. Since the late 1960s, however, their experiences reveal a more subordinate social status, measurable in public policies, mainstream representations, social patterns of prejudice, discrimination, and stereotyping, civic and political exclusion, and patterns of self-identification. ${ }^{6}$ Officially white yet in many ways experientially not white, the widespread stigmatization of Arabs in the United States continued largely unfettered throughout the latter part of the 20th century. Their civic and political isolation from mobilizations both by mainstream groups and people of color meant that their challenges to hostile media representations, textbook and pedagogical biases, and selective policy enforcement were largely ignored.

The origin of the subordination of Arab Americans lies not in historic American ideas about race, but rather in the much later emergence of the United States as a world superpower. Consequently, the impact of this subordination is different, particularly on an economic level, because it intervened in the ongoing trajectories of historically successful Arab American communities. ${ }^{7}$

These social processes can be traced as they played out on the experiences of the oldest and largest Arab Muslim community in metropolitan Chicago, the Palestinians. Palestinians (Christian and Muslim) were traders and shopkeepers on the south side of Chicago in the early 20th century, establishing an occupational niche that could absorb newcomers with low levels of human capital (Cainkar 1999). They lived behind or near their stores in African American neighborhoods until family migration accelerated after World War II. 
They then began moving southwest, uncontested as they shared residential space with other "white ethnics," largely Poles, Lithuanians, and Greeks. In the 1980s, like middle-class families in these other groups, Arabs (by then including Jordanians) began moving to the southwest suburbs. By the mid-1990s, more Arabs lived in the southwest suburbs than in the city, although many new immigrant and low-income Arab families continued to live near the former community core at 63rd and Kedzie.

The construction of the Arab Muslim community's first permanent mosque in suburban Bridgeview in 1982, followed by the opening of two Islamic schools, attracted Arab residential and commercial investment in the suburb. Together with the religious institutions, the wide range of Arab businesses that opened along Bridgeview's Harlem Avenue, including an Arab American bank, offered the Arab Muslim community a degree of institutional completeness. ${ }^{8}$

The Arabs, however, were viewed by many of the majority white suburbanites as "non-white" invaders. As their numbers grew (to ten percent in some southwest suburbs), they were increasingly seen as undesirable and unwelcome neighbors whose presence would lower a neighborhood's property values. ${ }^{9}$ For their part, Arabs in the suburbs claimed that they were socially and politically excluded, that their children were taught anti-Arab materials in the schools, that they were subject to more frequent police stops than whites, and that their organizations were hounded by federal agents. These sentiments matched those of Arabs on the southwest side of the city, who increasingly adopted a "people of color" identity, and shared organizational alliances with their now Latino and African American neighbors. More than anything else, Arab Americans complained about incessant representations of Arabs as terrorists by the American media; the marketing of films, games, and costumes that perpetuated these ideas; and unbalanced coverage of overseas events so as to promote an essentialized Arab character. These images created the conditions for their treatment as "others," and built social distance between them and their neighbors, as Arabs were seen as a web of inherent traits rather than as individual human beings.

All photos by Louise Cainkar, except as indicated. Photos may not be used without permission.

City and Society, Vol 17, No. 2 (December 2005): pg. 181-209. DOI. This article is (C) American Anthropological Association and permission has been granted for this version to appear in e-Publications@Marquette. American Anthropological Association does not grant permission for this article to be further copied/distributed or hosted elsewhere without the express permission from American Anthropological Association. 
NOT THE PUBLISHED VERSION; this is the author's final, peer-reviewed manuscript. The published version may be accessed by following the link in the citation at the bottom of the page.

These late 20th century urban American experiences intersected, in turn, with the global Islamic revival movement, which was evidenced in American cities in the 1990s by the heightened religiosity of new immigrant, formerly secular, and second generation Muslims. ${ }^{10}$ Mosque congregations and Islamic schools increased in number, along with commercial enterprises supporting a Muslim lifestyle. The change was visually perceptible in women's dress, as many women who did not do so before adopted the hijab and some began wearing long, Islamic-style coats. For many Arab American Muslims, Islam provided a sense of dignity and peace they found otherwise lacking in the American experience. Social processes of exclusion initially set in motion by essentialist discourses and political agendas were countered by embracing religion and spirituality, not a new phenomenon in American history.

As Islamic revival grew as a religious movement, political Islam rose in popularity in Muslim majority countries, and was highly critical of the policies exercised via American global hegemony. ${ }^{11}$ In the United States, essentialized constructions of violent and backwards Arabs were nearly seamlessly extended to the Muslim "enemy." The same representations were deployed, but instead of being about Arab culture they were about Islam and its "flawed civilization." Clash of civilizations, a term popularized by scholar Samuel Huntington (1996), became a common discourse in American society. While the immediately prior American enemies had been ideologies and their proponents-communism, socialism, and liberation theology-this enemy was a civilization embodied in more than 1 billion persons.

As Arab American Muslims became more religious, their differences from others in the communities in which they lived became more pronounced and more real. While Muslims experienced Islam as uplifting, it was frequently portrayed in the media as a violent and evil religion, setting American Muslims on a collision course with Americans who believed in the clash.

The post-9/11 backlash experiences of Arabs and Muslims in metropolitan Chicago can be understood in this historic context. Women wearing hijab experienced more attacks than other women

\footnotetext{
All photos by Louise Cainkar, except as indicated. Photos may not be used without permission.
}

City and Society, Vol 17, No. 2 (December 2005): pg. 181-209. DOI. This article is @ American Anthropological Association and permission has been granted for this version to appear in e-Publications@Marquette. American Anthropological Association does not grant permission for this article to be further copied/distributed or hosted elsewhere without the express permission from American Anthropological Association. 
and than men because of their dress, which symbolized membership in a group (Islamic civilization) perceived as morally different and antiAmerican. Incidents of verbal and physical assault on Arabs and Muslims as Arabs and Muslims declined earlier in diverse urban neighborhoods, partly because other racialized groups were less likely to buy into mainstream stereotypes, and because relationships between these groups were organizationally cultivated. On the other hand, Arabs and Muslims did not have organized relationships with their white suburban neighbors that could mitigate the socially created distance between the two groups. Instead, where Arabs lived in significant numbers, they were seen as a threat to neighborhood safety and to the suburban American dream. In these places, spitting and calls to "go back to your country" continue to occur and animosity towards the "Muslim race" remains. Institutional presence and constituting a significant economic force did not offer Arabs and Muslims safety. Instead, their institutions and businesses were the objects of attack after 9/11.

Two more recent post-9/11 events indicate positive trends that may begin to turn this situation around. Chicago-area Muslims donated 16,000 pounds of fresh ground beef to the Greater Chicago Food Depository in 2004, in celebration of Eid al-Adha (Feast of the Sacrifice of Abraham). This donation was the largest ever to the depository, which feeds the area's poor and homeless. Muslim leaders encouraged co-religionists to think of their duty to feed the hungry not just in terms of the poor overseas but also in "our own neighborhoods." Also in 2004, a group of mostly Palestinian Muslims won the right to build a mosque in southwest suburban Orland Park, despite a well-organized protest movement (and rebuff a few years earlier in a nearby suburb). City council members voted unanimously to annex the land and approve the construction permit, invoking the US Constitution and freedom of religion.

After 9/11, Arabs and Muslims received organizational support in defense of their civil rights at the metropolitan level, and many individuals came forward to protect them. But these measures alone are insufficient to undermine and destroy pervasive images and stereotypes. A necessary ingredient for the creation of safe space for 
NOT THE PUBLISHED VERSION; this is the author's final, peer-reviewed manuscript. The published version may be accessed by following the link in the citation at the bottom of the page.

Arabs and Muslims lies in building alliances that strengthen community-based relationships and break down socially constructed barriers.

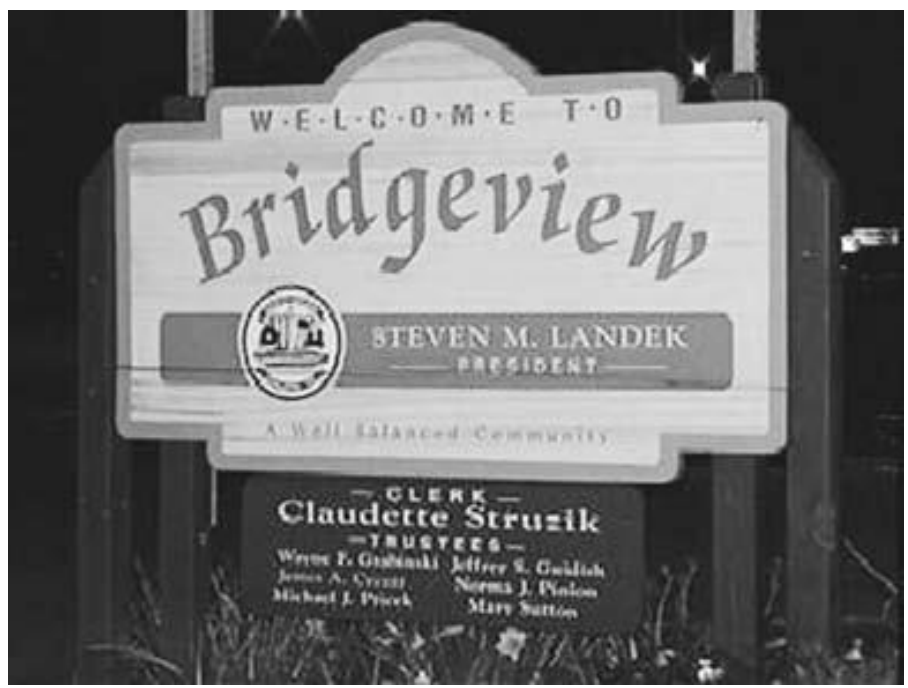

Space and Place in the Metropolis: Arabs and Muslims Seeking Safety

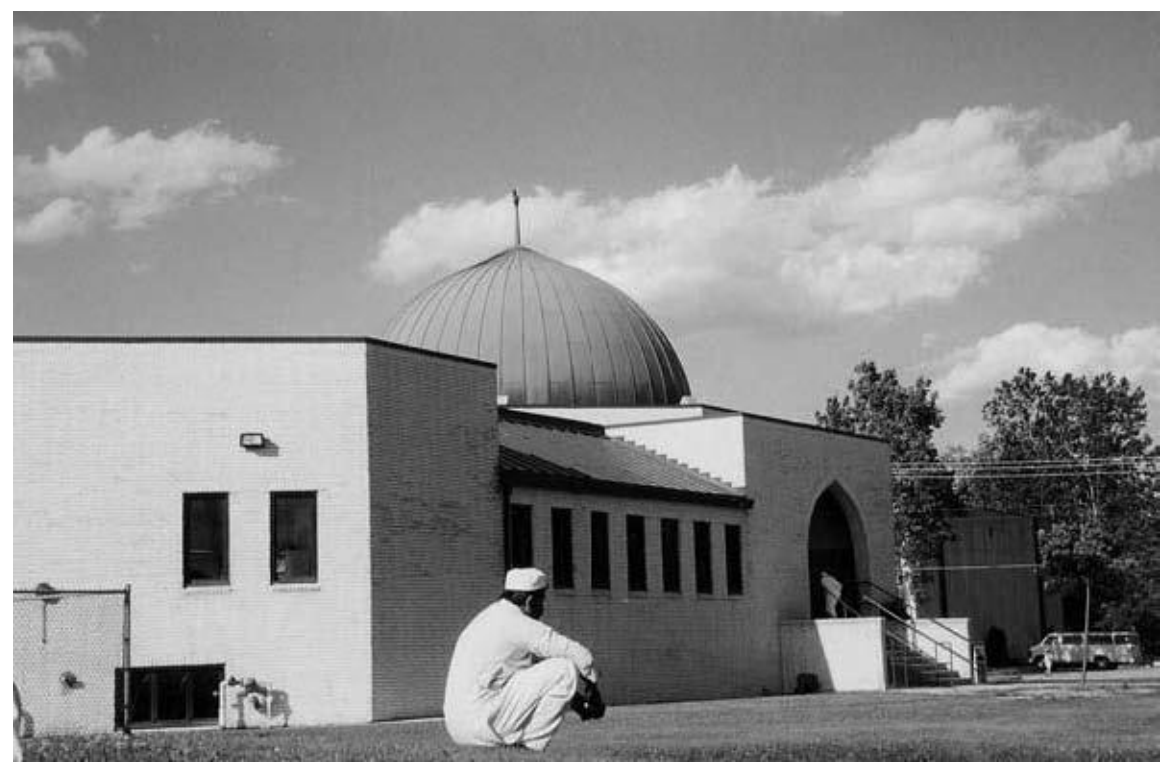

All photos by Louise Cainkar, except as indicated. Photos may not be used without permission.

City and Society, Vol 17, No. 2 (December 2005): pg. 181-209. DOI. This article is @ American Anthropological Association and permission has been granted for this version to appear in e-Publications@Marquette. American Anthropological Association does not grant permission for this article to be further copied/distributed or hosted elsewhere without the express permission from American Anthropological Association. 


\section{The Unfulfilled Dream of Return}

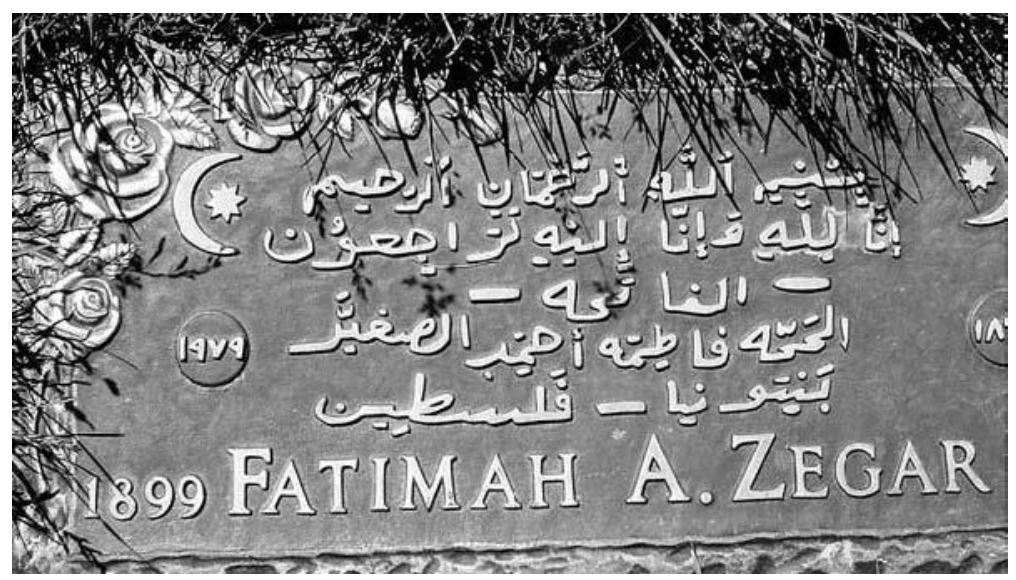

Palestinian Arabs first migrated to the United States at the turn of the 20th Century. In Chicago they initially settled on the near south side of the city. Over time, their numbers grew as did their trading and shop keeping niche on Chicago's south side. Residentially, they moved in a southwest trajectory from the urban center. By the 1970s, a generation of Palestinians had lived and died in Chicago. Most were from the area of Palestine now known as the Israeli-occupied West Bank.

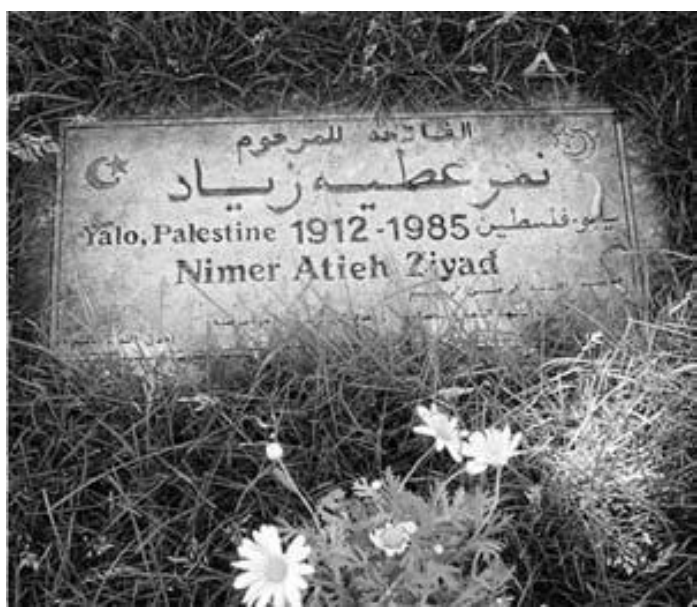

All photos by Louise Cainkar, except as indicated. Photos may not be used without permission.

City and Society, Vol 17, No. 2 (December 2005): pg. 181-209. DOI. This article is @ American Anthropological Association and permission has been granted for this version to appear in e-Publications@Marquette. American Anthropological Association does not grant permission for this article to be further copied/distributed or hosted elsewhere without the express permission from American Anthropological Association. 
NOT THE PUBLISHED VERSION; this is the author's final, peer-reviewed manuscript. The published version may be accessed by following the link in the citation at the bottom of the page.

\section{In the Name of God the Merciful and Compassionate We belong to God and to God we return}

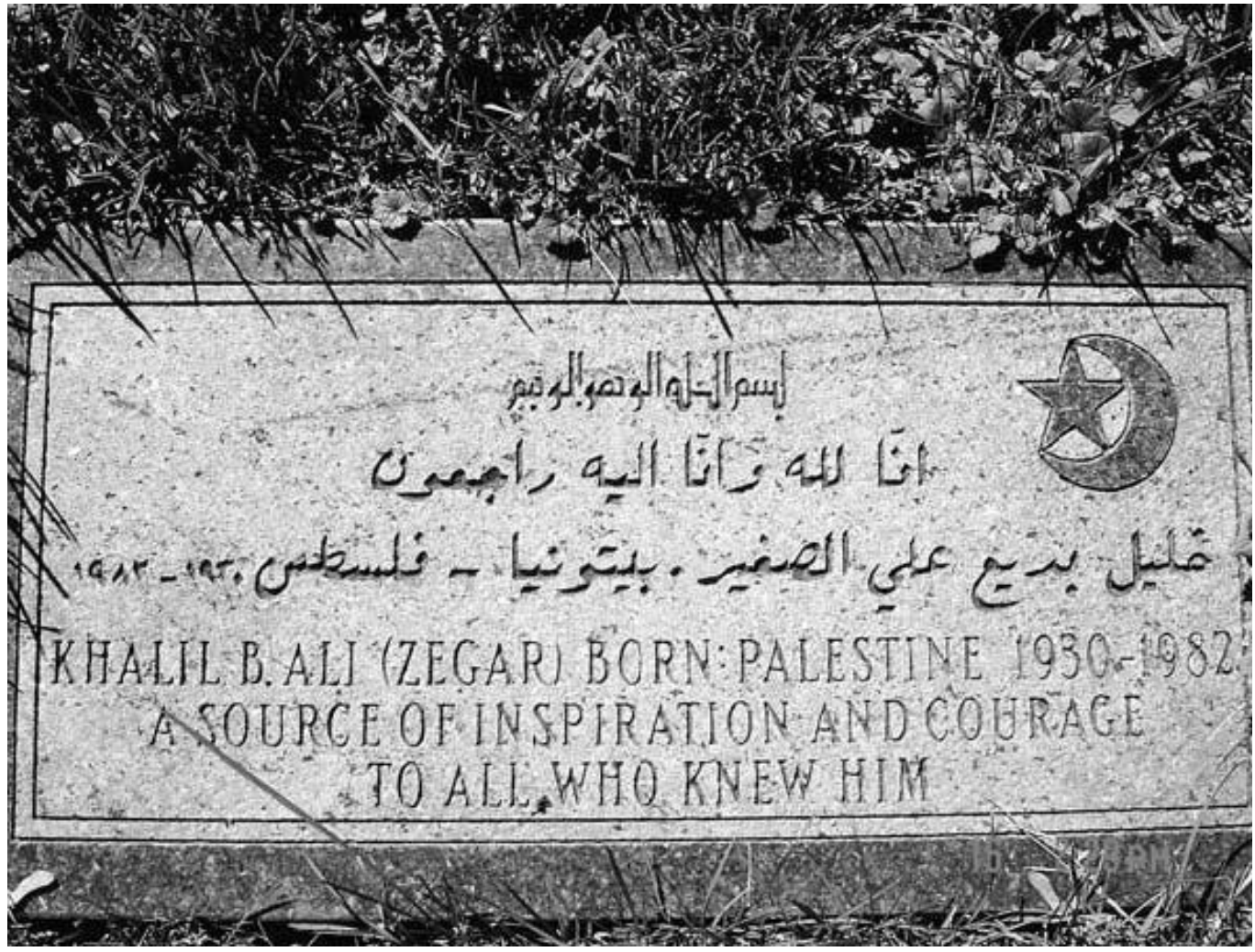

The gravestone of Khalil Badea Ali Al-Saghyr (1930-1982) from

Betunia, Palestine. The dream of most early Palestinian immigrants was to work hard, save money, and retire under their grape arbors in Palestine. Many never saw this earthly dream fulfilled. They were instead buried in the Muslim section of Evergreen Cemetery at 8700 south Kedzie Avenue.

All photos by Louise Cainkar, except as indicated. Photos may not be used without permission.

City and Society, Vol 17, No. 2 (December 2005): pg. 181-209. DOI. This article is @ American Anthropological Association and permission has been granted for this version to appear in e-Publications@Marquette. American Anthropological Association does not grant permission for this article to be further copied/distributed or hosted elsewhere without the express permission from American Anthropological Association. 


\section{Demographic Growth and Ethnic Market Expansion}

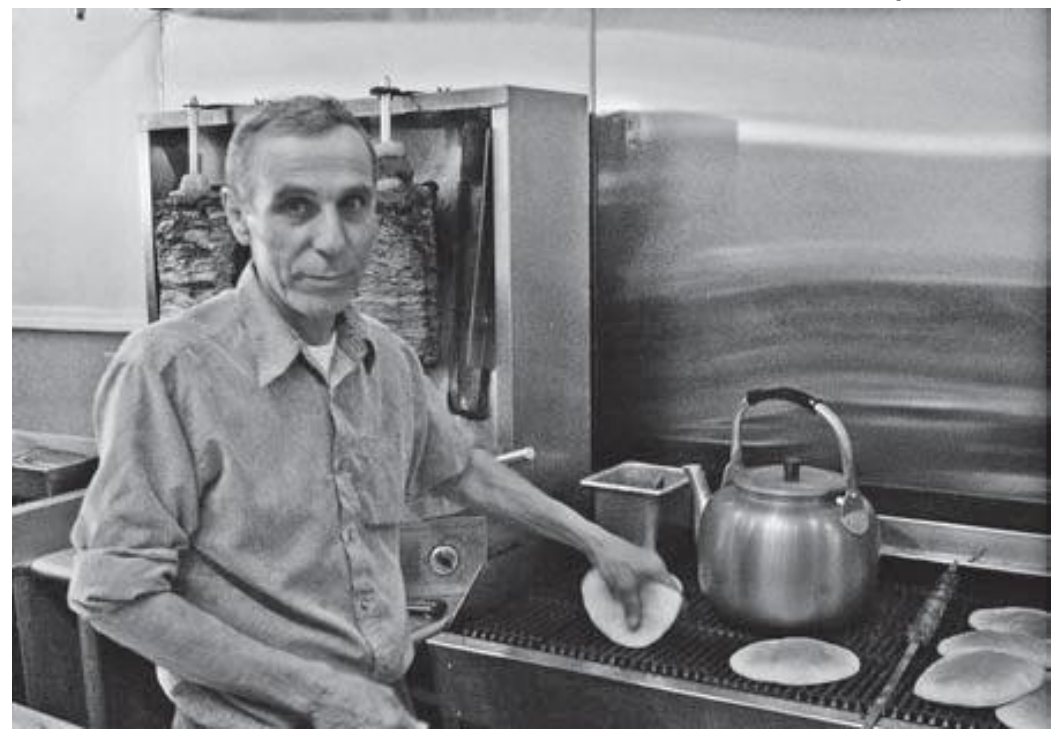

Growth in the

Palestinian community's size, through migration and childbirth, provided the conditions for an expanding ethnic market. Newer communities of Jordanians and later Yemenis on the south side enhanced the demand for Arabic goods and services. In the 1980s businesses catering to Palestinians and other Arabs radiated in a southwest trajectory from the center of the southwest side Arab community at 63rd and Kedzie.

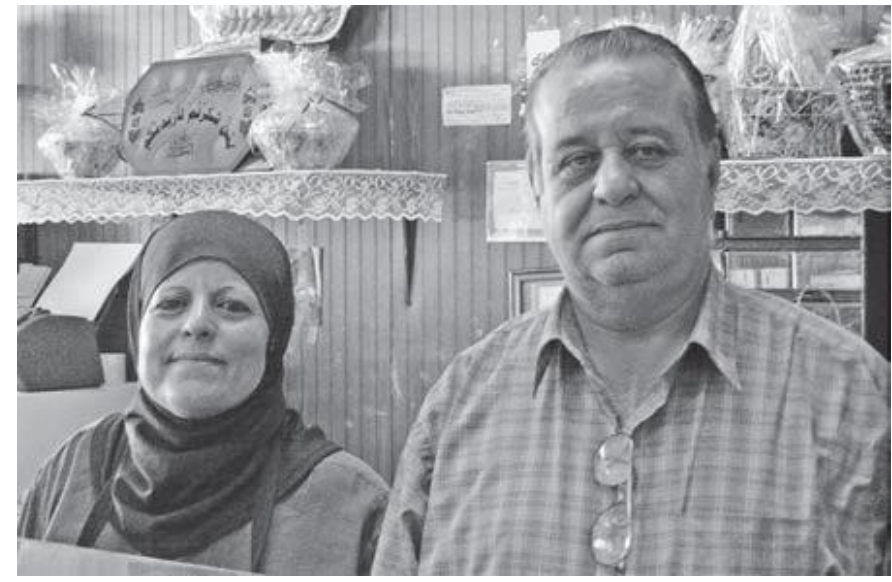

All photos by Louise Cainkar, except as indicated. Photos may not be used without permission.

City and Society, Vol 17, No. 2 (December 2005): pg. 181-209. DOI. This article is @ American Anthropological Association and permission has been granted for this version to appear in e-Publications@Marquette. American Anthropological Association does not grant permission for this article to be further copied/distributed or hosted elsewhere without the express permission from American Anthropological Association. 
NOT THE PUBLISHED VERSION; this is the author's final, peer-reviewed manuscript. The published version may be accessed by following the link in the citation at the bottom of the page.

\section{Diasporic Identities}

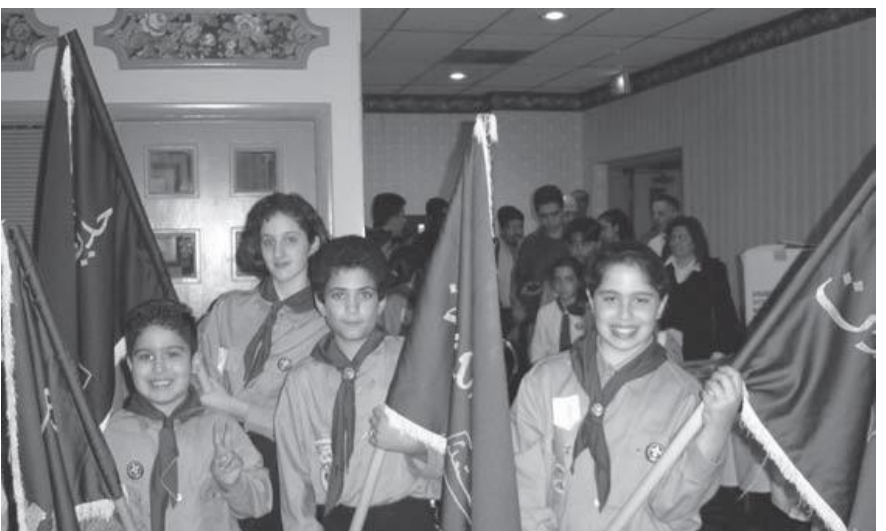

uslims as terrorists and discourses represent them as persons with uncivilized values.

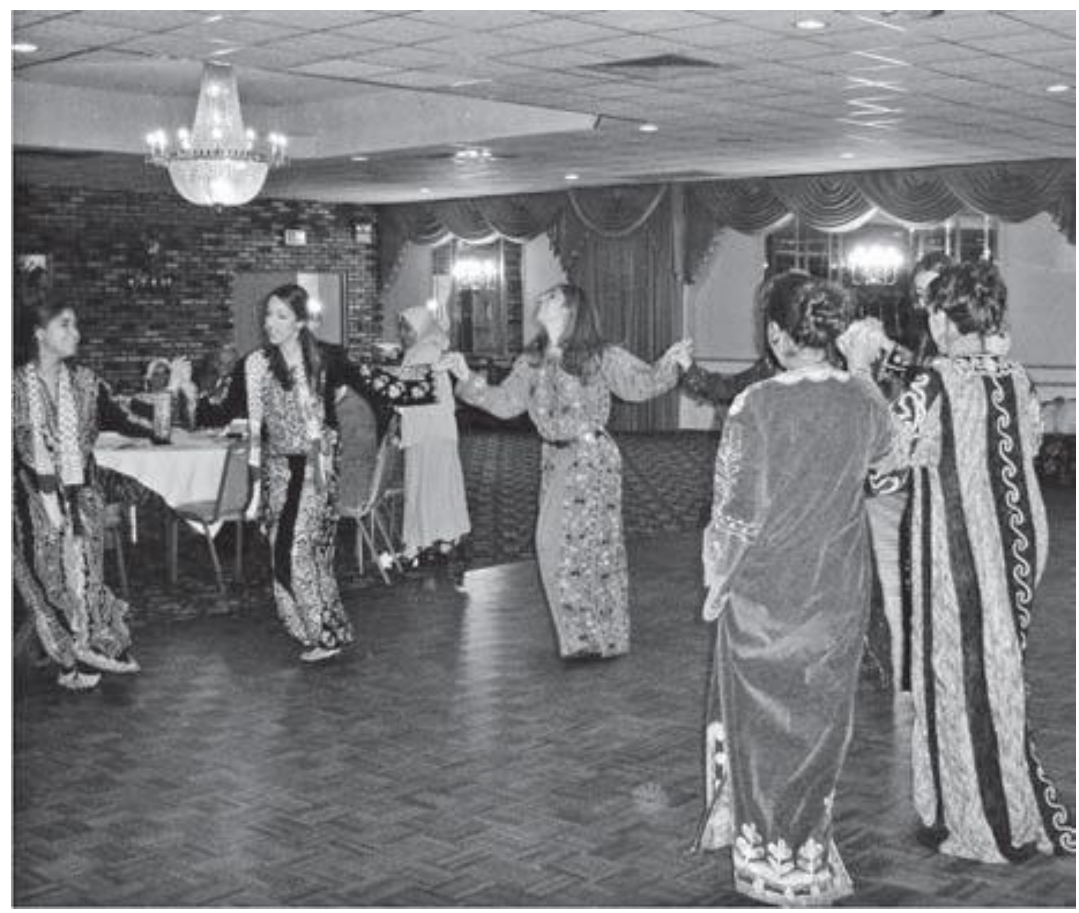

Palestinian women's organizations have played key political, social, educational, and cultural roles in the diasporic community. Taking active steps to resist erasure, they continue to wear traditional Palestinian embroidered dresses and dance the debke, an Arabic line dance.

All photos by Louise Cainkar, except as indicated. Photos may not be used without permission.

City and Society, Vol 17, No. 2 (December 2005): pg. 181-209. DOI. This article is @ American Anthropological Association and permission has been granted for this version to appear in e-Publications@Marquette. American Anthropological Association does not grant permission for this article to be further copied/distributed or hosted elsewhere without the express permission from American Anthropological Association. 
NOT THE PUBLISHED VERSION; this is the author's final, peer-reviewed manuscript. The published version may be accessed by following the link in the citation at the bottom of the page.
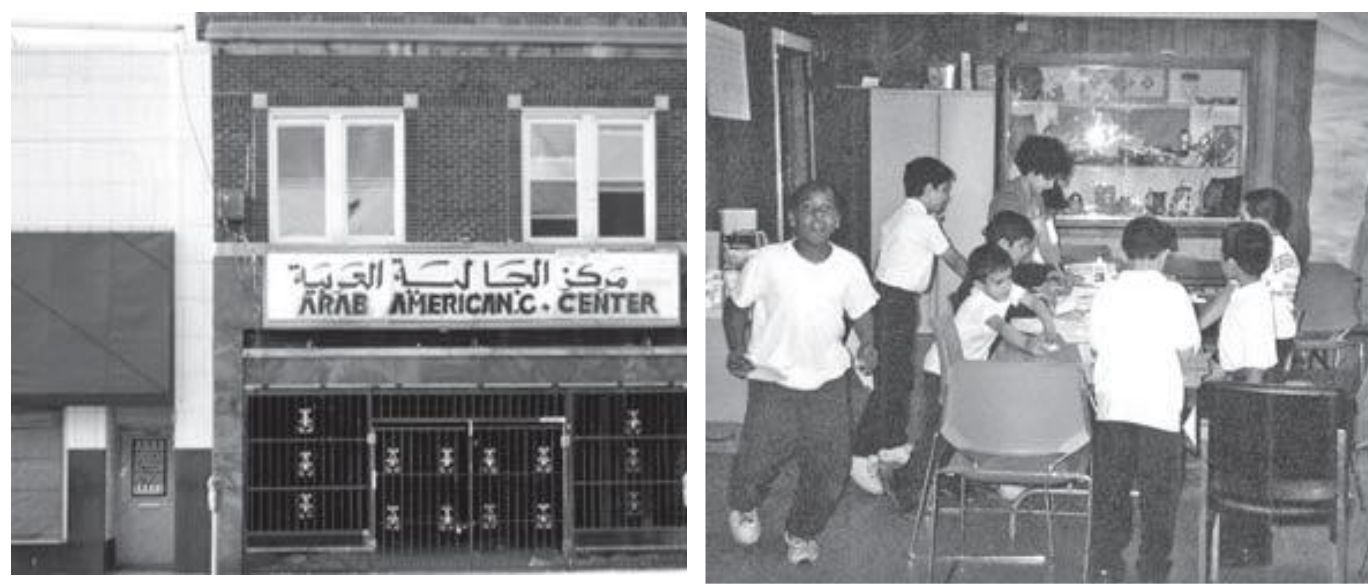

\section{Diversity: A Resource for Tolerance}

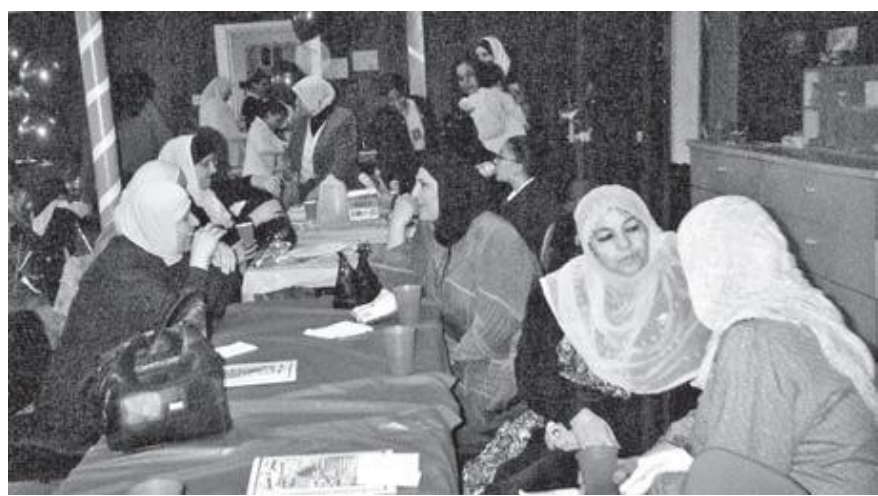

Despite movement of Arab families to the southwest suburbs, many remain near the community's historic core. The Arab community center (AAAN) has programs for women and youth; the latter are now as likely to be African American or Latino as Arab.

The multi-racial/ethnic character of the southwest side, and relationships built between communities by the AAAN, Southwest Youth Collaborative, and Inner City Muslim Action Network, curtailed Post 9/11 backlash

Image unavailable due to third-party copyright restrictions. Please see definitive published version to view image: http://dx.doi.org/10.1525/city.2005.17.2.181. against Arabs and Muslims sooner than in the southwest suburbs.

All photos by Louise Cainkar, except as indicated. Photos may not be used without permission.

City and Society, Vol 17, No. 2 (December 2005): pg. 181-209. DOI. This article is @ American Anthropological Association and permission has been granted for this version to appear in e-Publications@Marquette. American Anthropological Association does not grant permission for this article to be further copied/distributed or hosted elsewhere without the express permission from American Anthropological Association. 
NOT THE PUBLISHED VERSION; this is the author's final, peer-reviewed manuscript. The published version may be accessed by following the link in the citation at the bottom of the page.

\section{Scripting the Strip Mall}

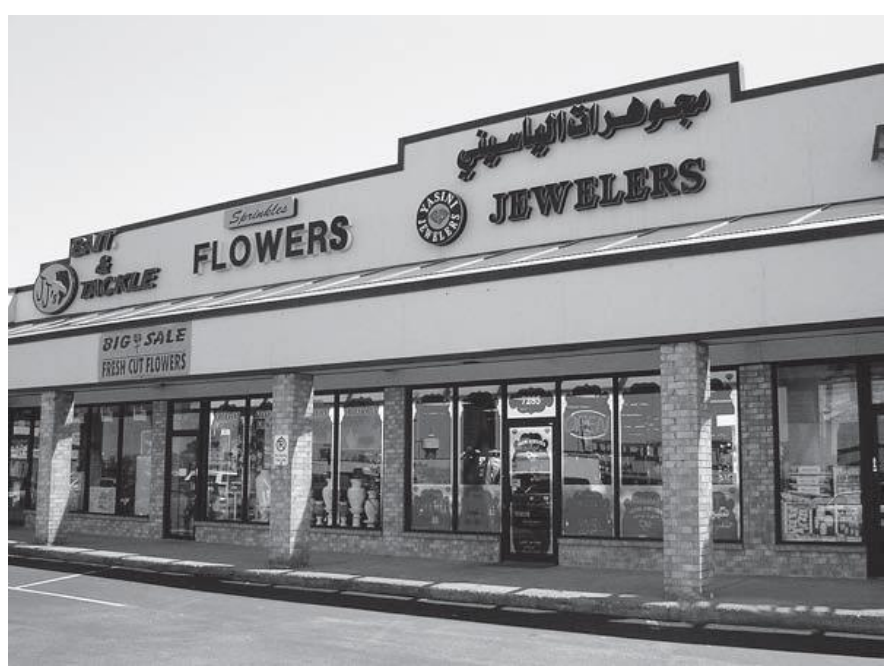

By the 1990s, a large share of the southwest-side Arab community had moved to Bridgeview and nearby suburbs. By 2000, suburban businesses catering to an Arab clientele would far outnumber those of Chicago's southwest side.

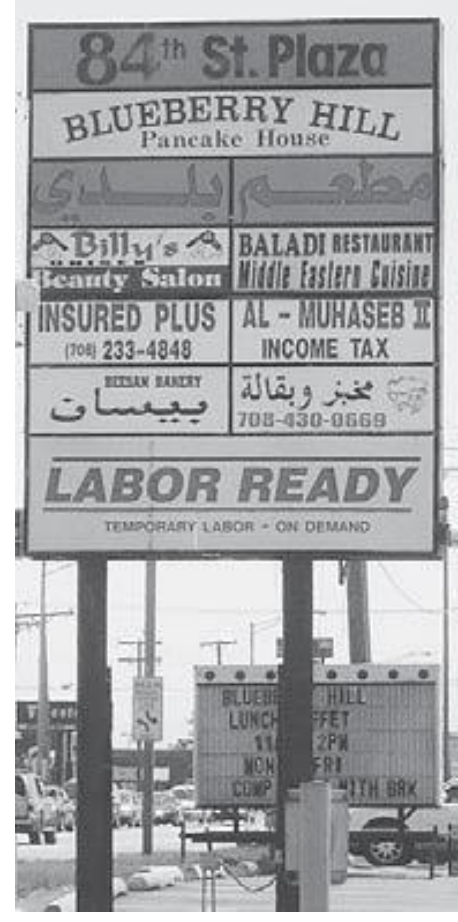

All photos by Louise Cainkar, except as indicated. Photos may not be used without permission.

City and Society, Vol 17, No. 2 (December 2005): pg. 181-209. DOI. This article is @ American Anthropological Association and permission has been granted for this version to appear in e-Publications@Marquette. American Anthropological Association does not grant permission for this article to be further copied/distributed or hosted elsewhere without the express permission from American Anthropological Association. 


\section{The Bridgeview Mosque}

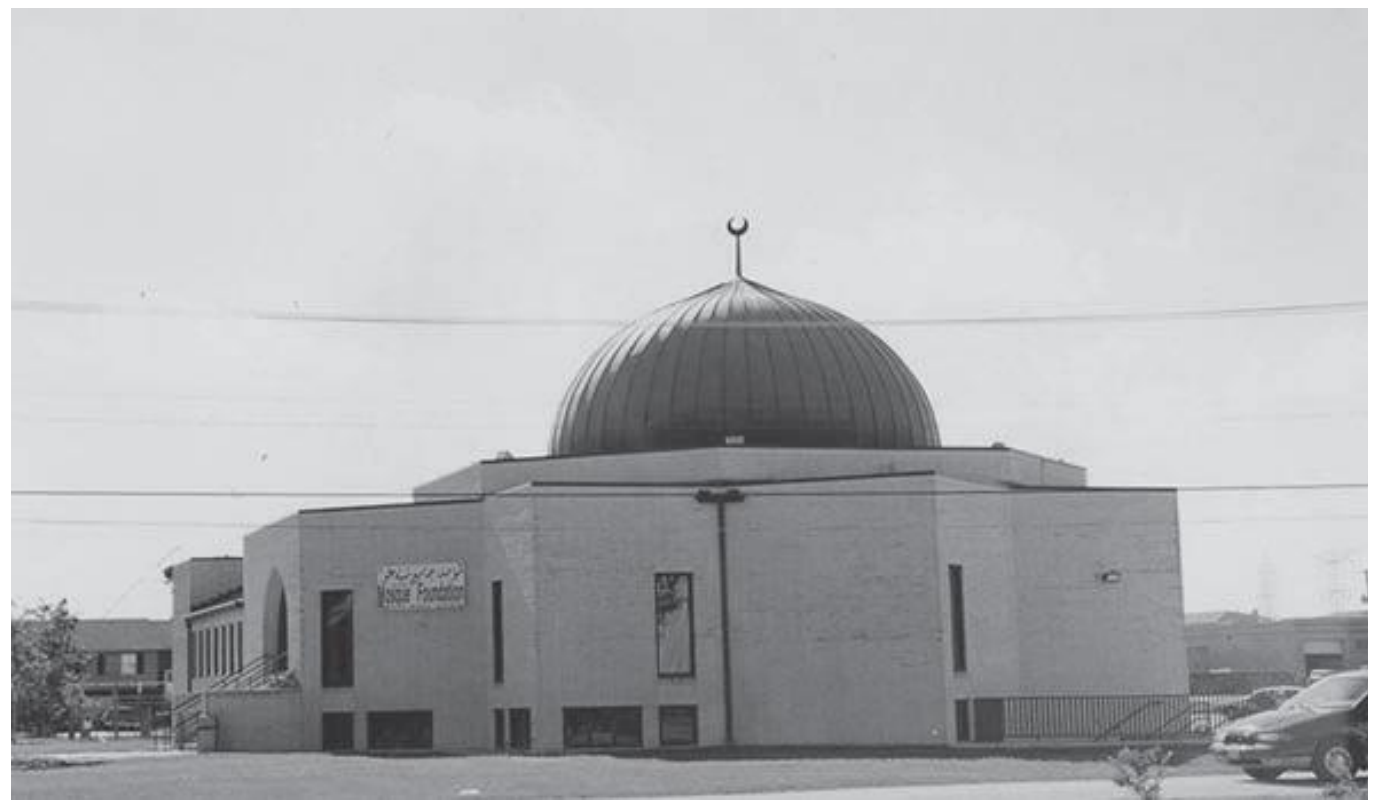

After years of makeshift, storefront mosques, the largely

Palestinian Muslim community of the southwest side built a mosque on land it purchased in southwest suburban Bridgeview. The mosque was completed in 1982, before the Arab community had become predominantly suburban.

Image unavailable due to third-party copyright restrictions. Please see definitive published version to view image: http://dx.doi.org/10.1525/city.2005.17.2.181. 
NOT THE PUBLISHED VERSION; this is the author's final, peer-reviewed manuscript. The published version may be accessed by following the link in the citation at the bottom of the page.

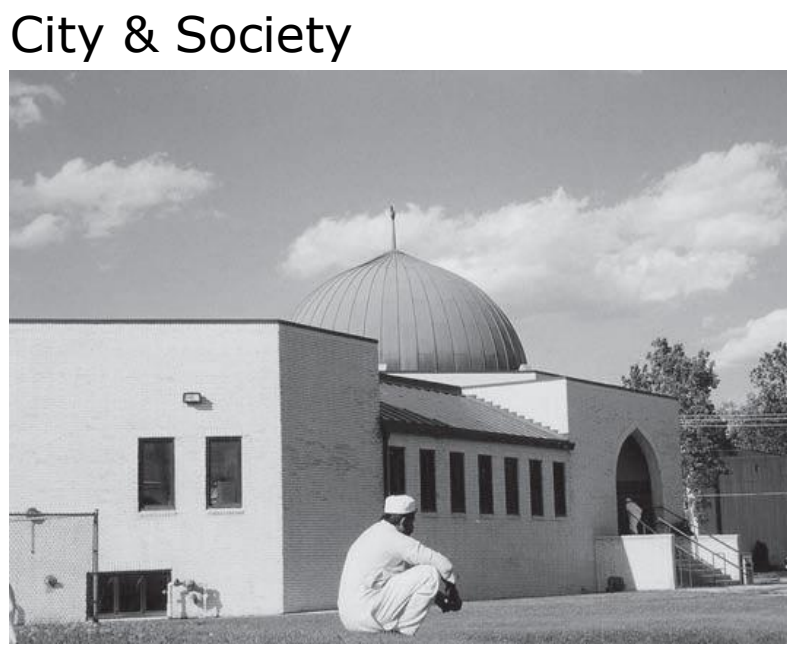

\section{The Ecological and Institutional Basis of Bridgeview's Muslim Quarter}

The mosque was built in a bounded quadrant of suburban Bridgeview. Sealed on the west by Interstate 294 , on the south by railroad tracks, and on the north by warehouses, the only entree to the area was from Harlem Avenue on the east. Arab commercial and institutional development of the area drew Arab families to purchase homes near the mosque.

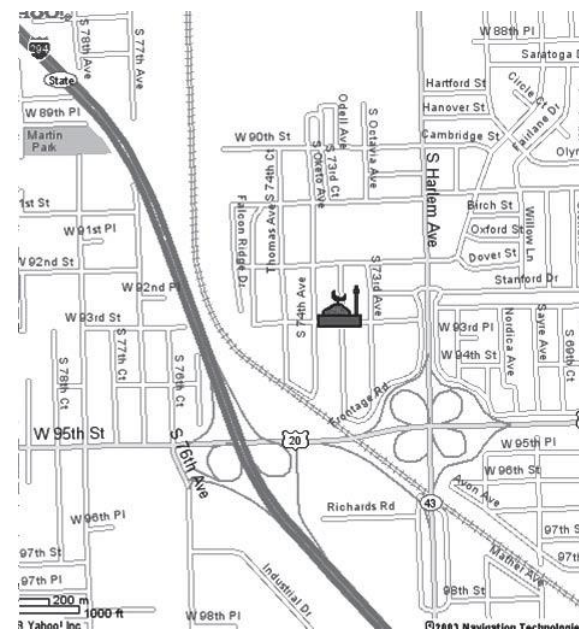

All photos by Louise Cainkar, except as indicated. Photos may not be used without permission.

City and Society, Vol 17, No. 2 (December 2005): pg. 181-209. DOI. This article is (C) American Anthropological Association and permission has been granted for this version to appear in e-Publications@Marquette. American Anthropological Association does not grant permission for this article to be further copied/distributed or hosted elsewhere without the express permission from American Anthropological Association. 
NOT THE PUBLISHED VERSION; this is the author's final, peer-reviewed manuscript. The published version may be accessed by following the link in the citation at the bottom of the page.

\title{
Islamic \\ Educational \\ Institutions
}

\author{
A small elementary \\ school for girls was \\ established inside the \\ mosque in the 1980s. \\ In the following decade, \\ the school moved to its \\ own facility. Later, an \\ Islamic secondary \\ school was built. Both \\ are adjacent to the \\ Bridgeview mosque.
}
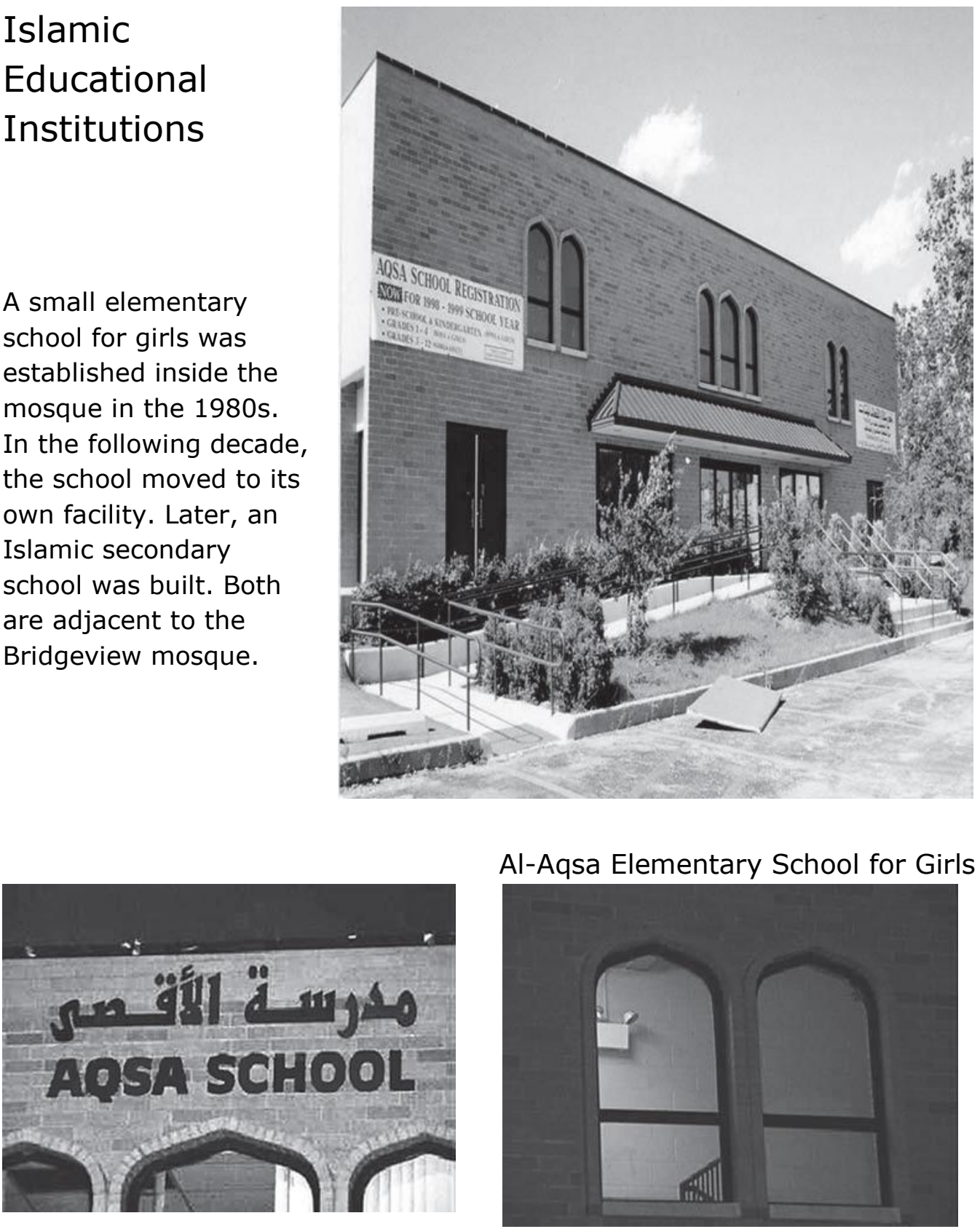

All photos by Louise Cainkar, except as indicated. Photos may not be used without permission.

City and Society, Vol 17, No. 2 (December 2005): pg. 181-209. DOI. This article is (C) American Anthropological Association and permission has been granted for this version to appear in e-Publications@Marquette. American Anthropological Association does not grant permission for this article to be further copied/distributed or hosted elsewhere without the express permission from American Anthropological Association. 
NOT THE PUBLISHED VERSION; this is the author's final, peer-reviewed manuscript. The published version may be accessed by following the link in the citation at the bottom of the page.

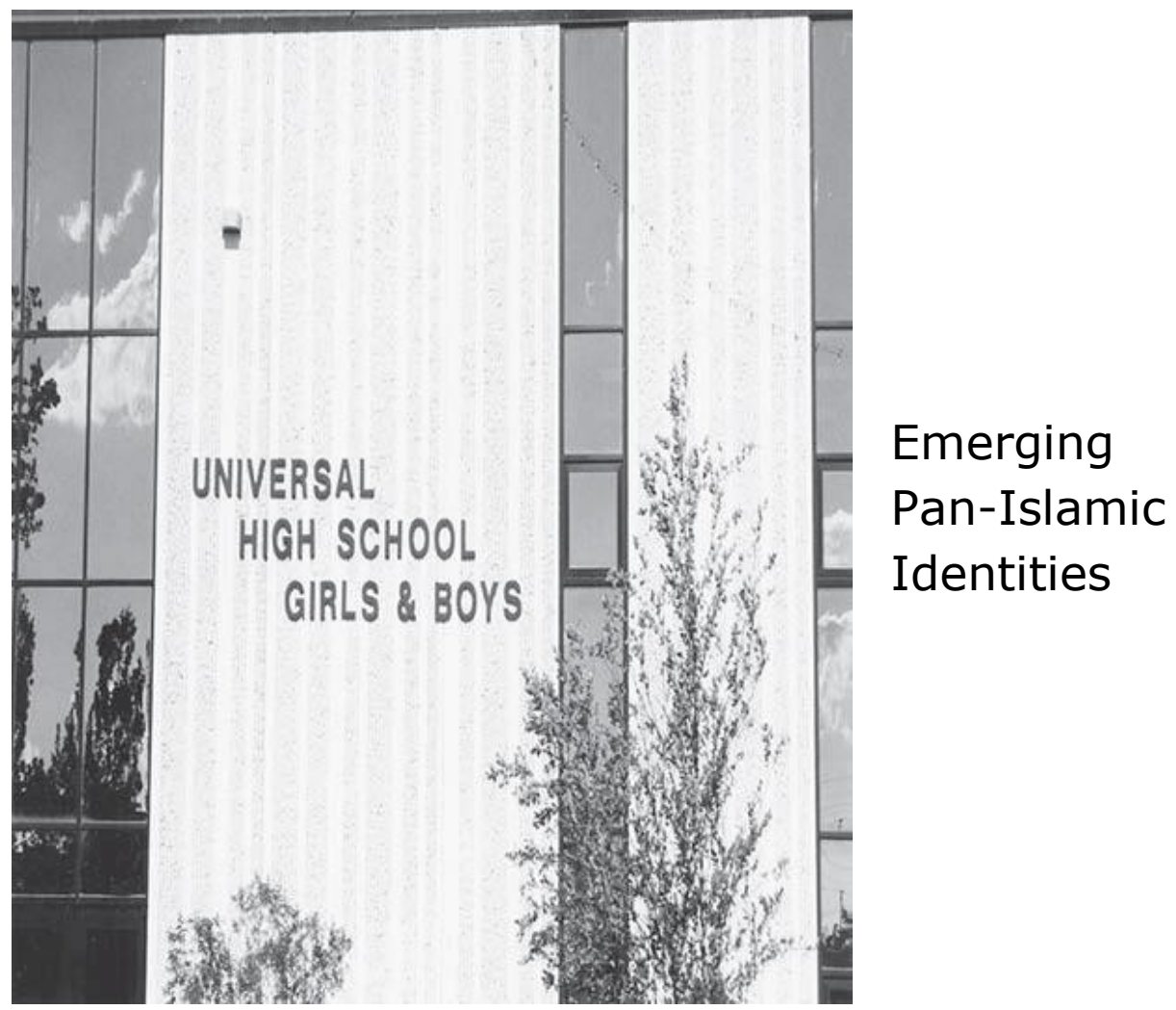

The mosque and Islamic schools now have a wide range of Muslim congregants, pupils, and faculty. A pan-Islamic identity is increasingly claiming formerly dominant national and ethnic identities.

Image unavailable due to third-party copyright restrictions. Please see definitive published version to view image:

http://dx.doi.org/10.1525/city.2005.17.2.181 


\section{Demographic Change: An Arab Muslim Neighborhood Emerges}

Image unavailable due to third-party copyright restrictions. Please see definitive published version to view image:

http://dx.doi.org/10.1525/city.2005.17.2.181

Over the 10 year period from 1990-2000, the

Arab population of Bridgeview quadrupled

and the middle-class residential

neighborhood around the mosque became more

than $80 \%$ Arab and Muslim, with

Palestinians in the majority.

Image unavailable due to third-party copyright restrictions. Please see definitive published version to view image: http://dx.doi.org/10.1525/city.2005.17.2.181

All photos by Louise Cainkar, except as indicated. Photos may not be used without permission.

City and Society, Vol 17, No. 2 (December 2005): pg. 181-209. DOI. This article is @ American Anthropological Association and permission has been granted for this version to appear in e-Publications@Marquette. American Anthropological Association does not grant permission for this article to be further copied/distributed or hosted elsewhere without the express permission from American Anthropological Association. 
NOT THE PUBLISHED VERSION; this is the author's final, peer-reviewed manuscript. The published version may be accessed by following the link in the citation at the bottom of the page.

\section{Harlem Avenue: Approaching Institutional Completeness}

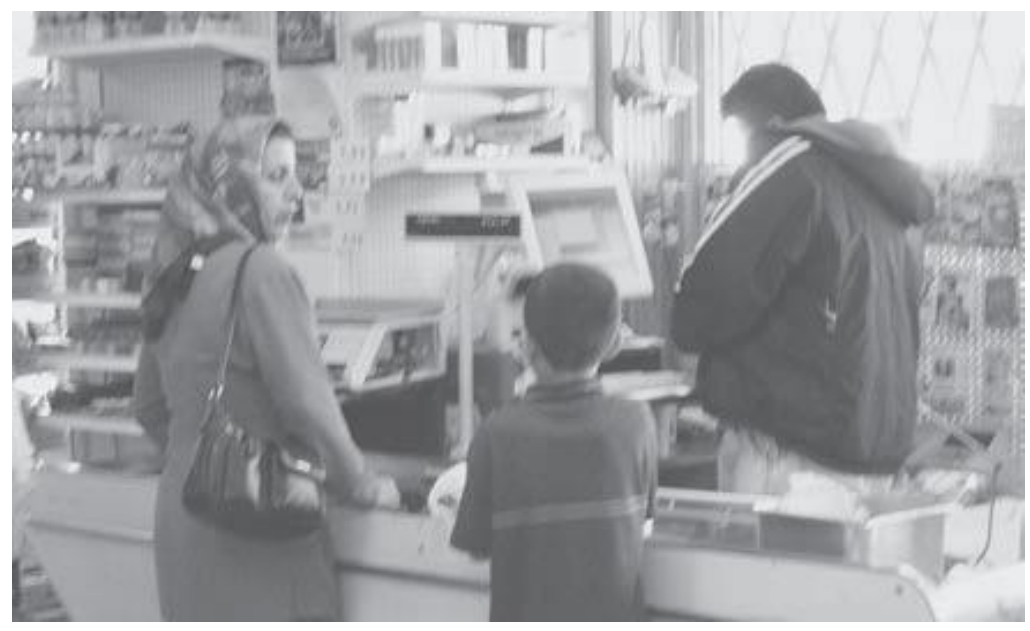

The area near the Bridgeview mosque and Harlem Avenue now approaches an institutionally complete financial, commercial, spiritual, educational, and social arena for Arabs and Muslims.

All photos by Louise Cainkar, except as indicated. Photos may not be used without permission.

City and Society, Vol 17, No. 2 (December 2005): pg. 181-209. DOI. This article is (C) American Anthropological Association and permission has been granted for this version to appear in e-Publications@Marquette. American Anthropological Association does not grant permission for this article to be further copied/distributed or hosted elsewhere without the express permission from American Anthropological Association. 
NOT THE PUBLISHED VERSION; this is the author's final, peer-reviewed manuscript. The published version may be accessed by following the link in the citation at the bottom of the page.

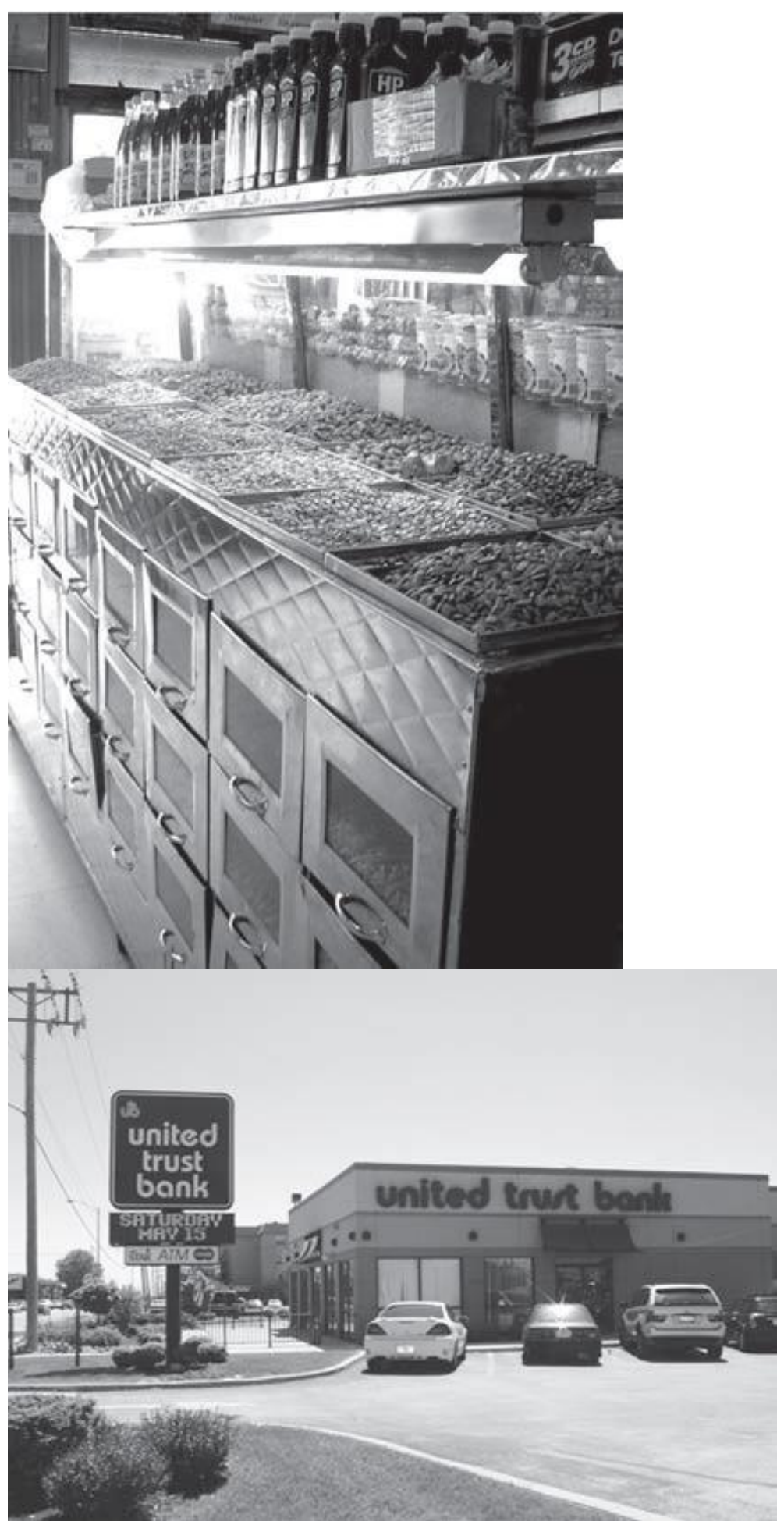

All photos by Louise Cainkar, except as indicated. Photos may not be used without permission.

City and Society, Vol 17, No. 2 (December 2005): pg. 181-209. DOI. This article is (C) American Anthropological Association and permission has been granted for this version to appear in e-Publications@Marquette. American Anthropological Association does not grant permission for this article to be further copied/distributed or hosted elsewhere without the express permission from American Anthropological Association. 
NOT THE PUBLISHED VERSION; this is the author's final, peer-reviewed manuscript. The published version may be accessed by following the link in the citation at the bottom of the page.

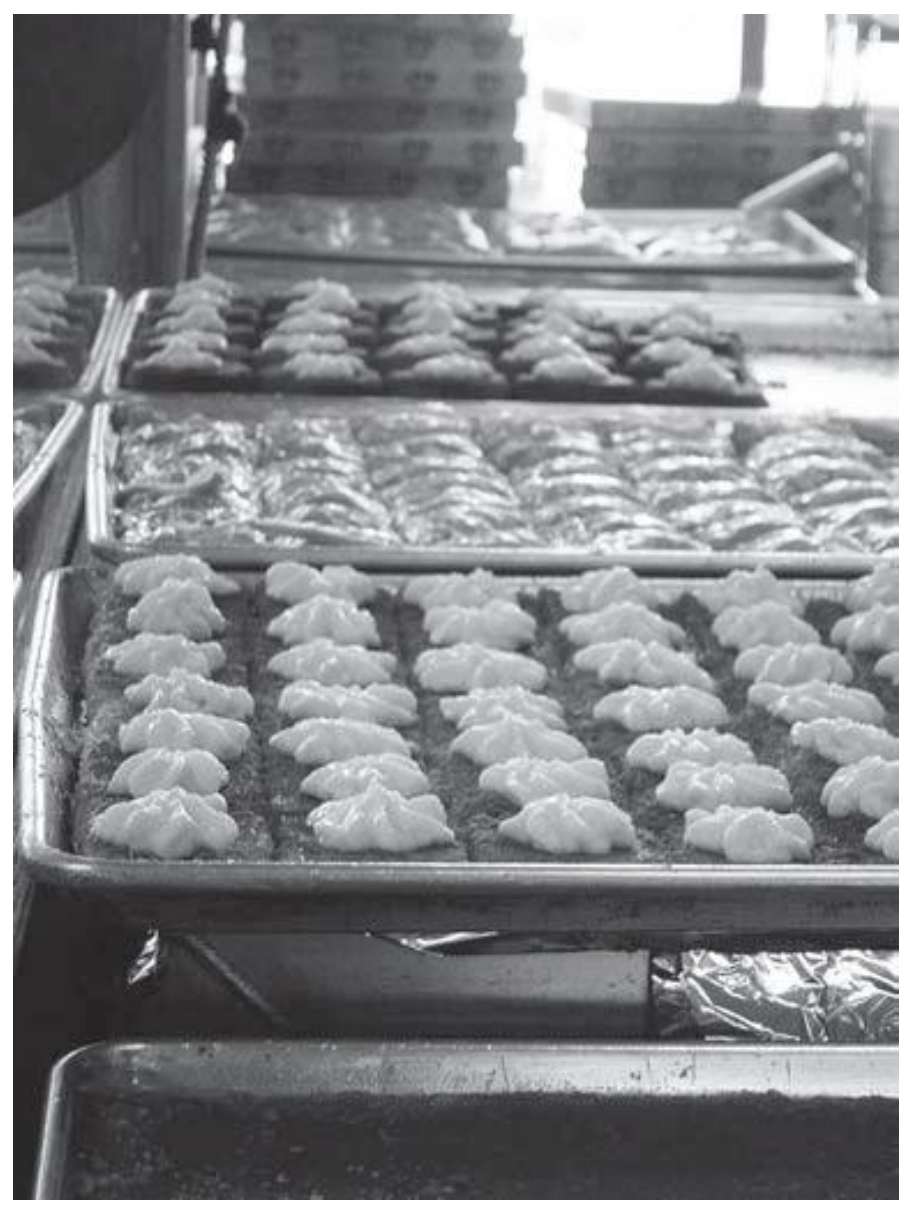

All photos by Louise Cainkar, except as indicated. Photos may not be used without permission.

City and Society, Vol 17, No. 2 (December 2005): pg. 181-209. DOI. This article is @ American Anthropological Association and permission has been granted for this version to appear in e-Publications@Marquette. American Anthropological Association does not grant permission for this article to be further copied/distributed or hosted elsewhere without the express permission from American Anthropological Association. 
NOT THE PUBLISHED VERSION; this is the author's final, peer-reviewed manuscript. The published version may be accessed by following the link in the citation at the bottom of the page.
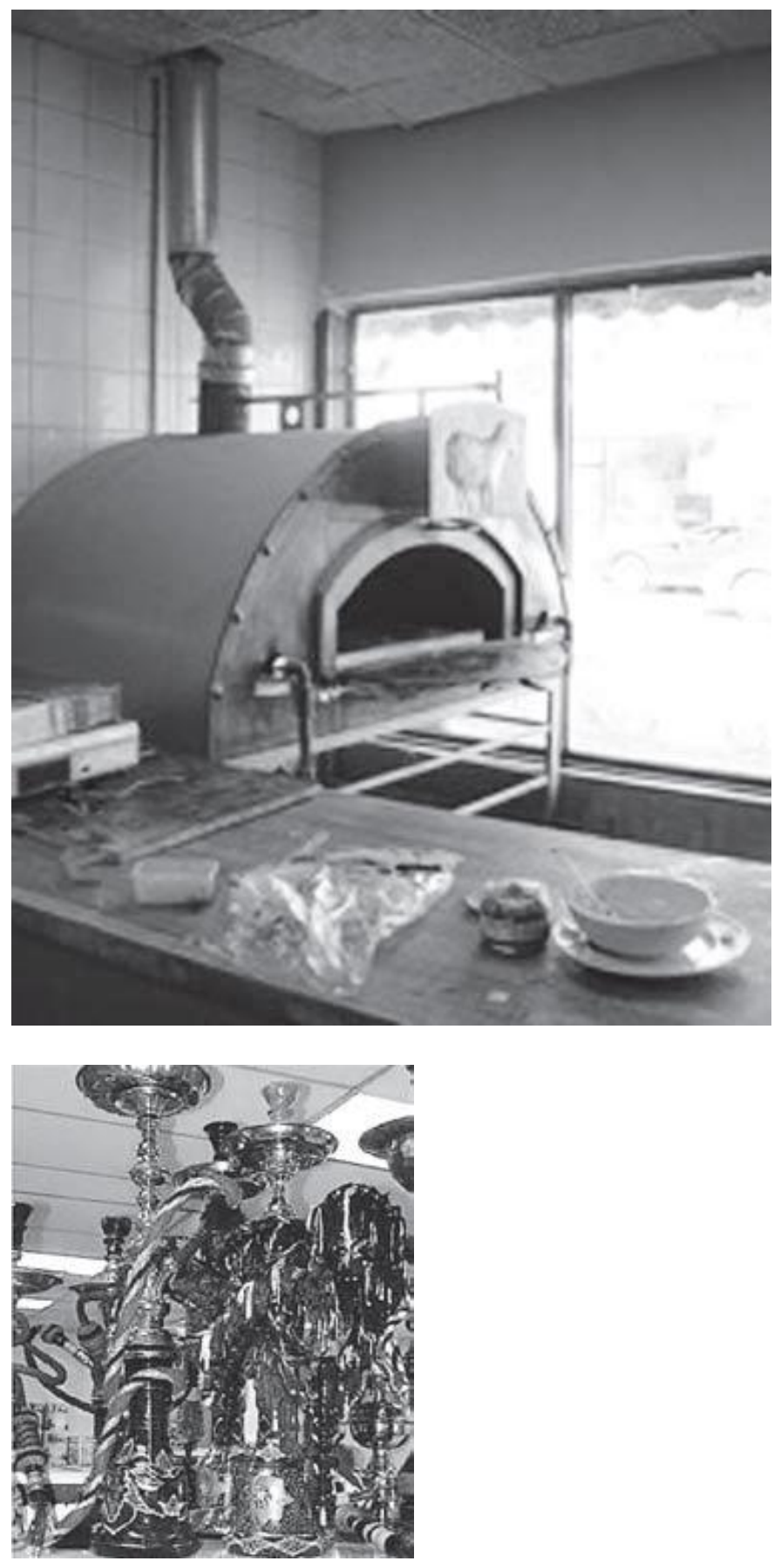

All photos by Louise Cainkar, except as indicated. Photos may not be used without permission.

City and Society, Vol 17, No. 2 (December 2005): pg. 181-209. DOI. This article is (C) American Anthropological Association and permission has been granted for this version to appear in e-Publications@Marquette. American Anthropological Association does not grant permission for this article to be further copied/distributed or hosted elsewhere without the express permission from American Anthropological Association. 
NOT THE PUBLISHED VERSION; this is the author's final, peer-reviewed manuscript. The published version may be accessed by following the link in the citation at the bottom of the page.

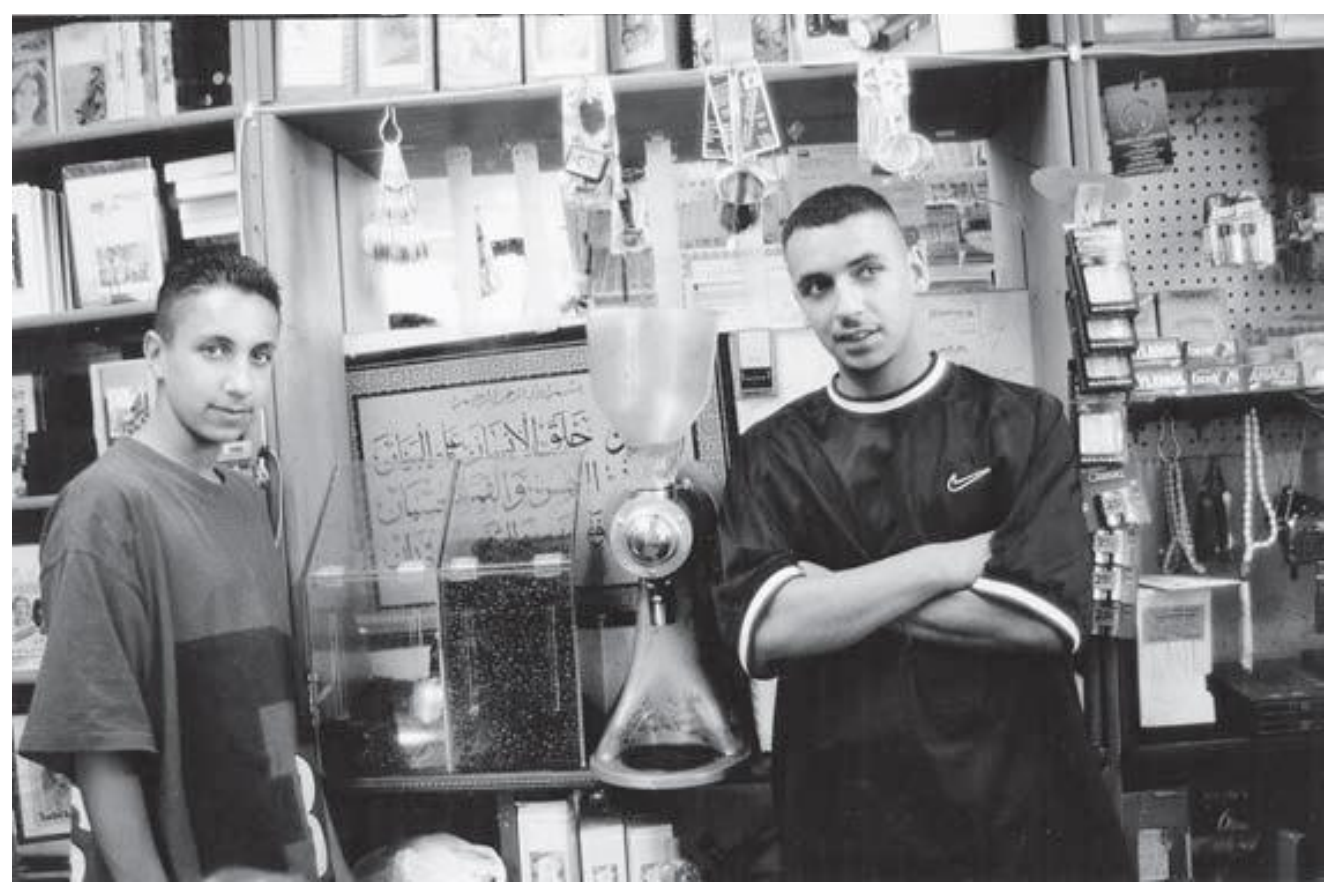

\section{Global Islamic Revival Intersects with the American Experience}

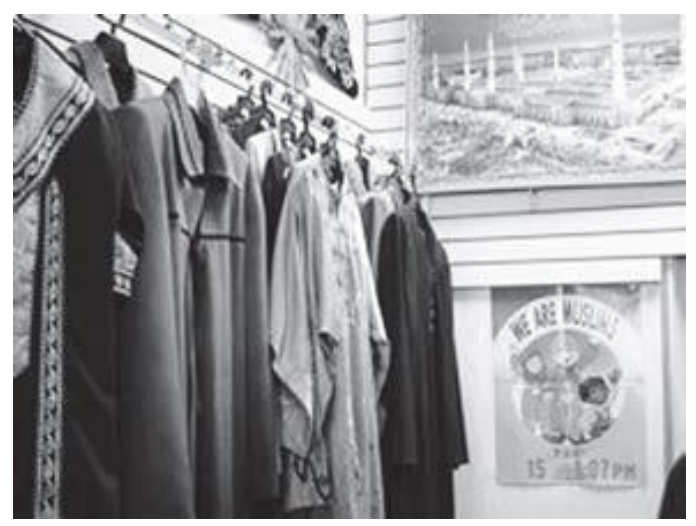

All photos by Louise Cainkar, except as indicated. Photos may not be used without permission.

City and Society, Vol 17, No. 2 (December 2005): pg. 181-209. DOI. This article is @ American Anthropological Association and permission has been granted for this version to appear in e-Publications@Marquette. American Anthropological Association does not grant permission for this article to be further copied/distributed or hosted elsewhere without the express permission from American Anthropological Association. 
NOT THE PUBLISHED VERSION; this is the author's final, peer-reviewed manuscript. The published version may be accessed by following the link in the citation at the bottom of the page.
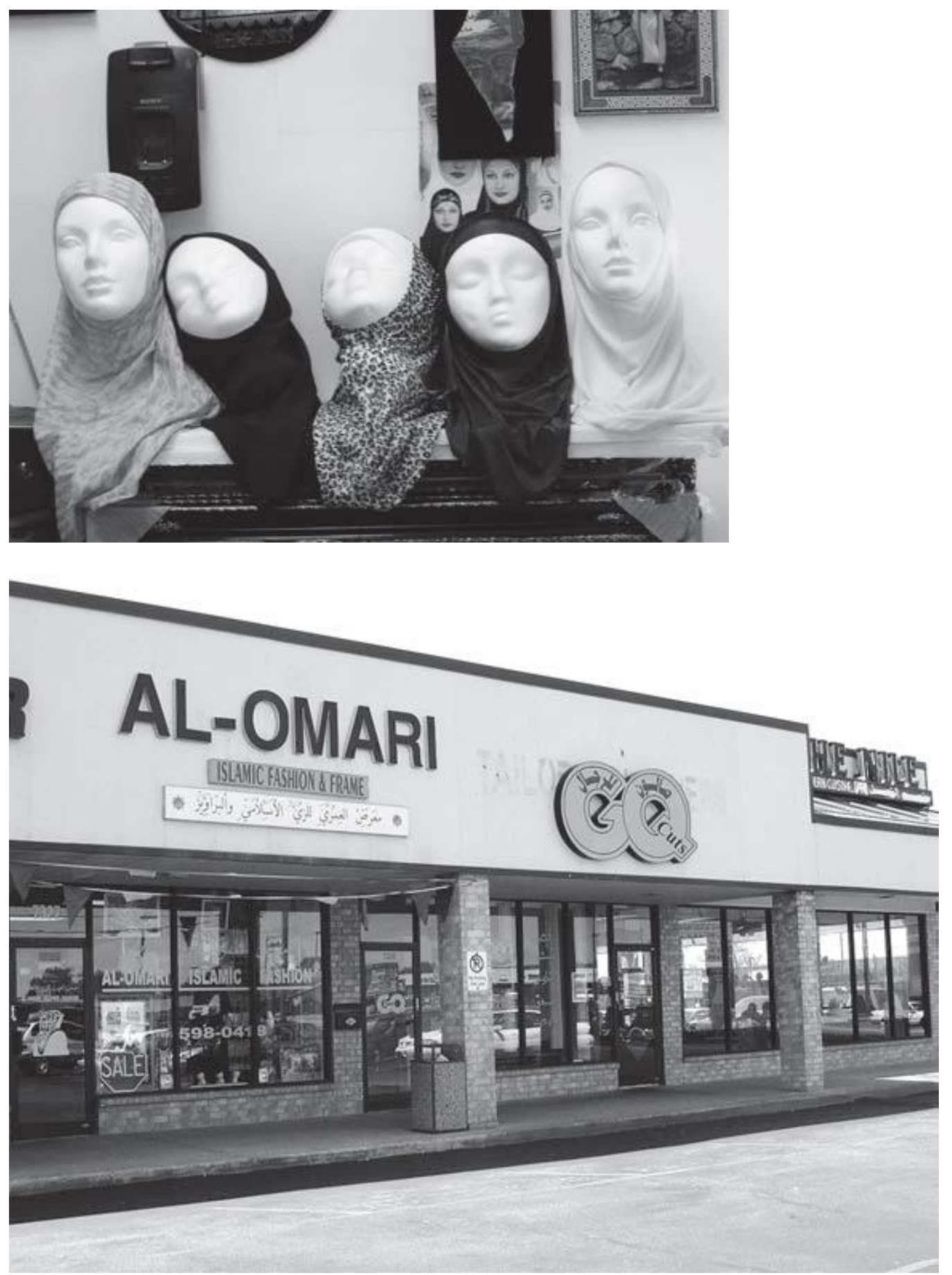

Global Islamic revival surged in the Chicago area in the mid 1990s. Its popularity spurred the growth of "Islamic fashion" commerce and industries.

All photos by Louise Cainkar, except as indicated. Photos may not be used without permission.

City and Society, Vol 17, No. 2 (December 2005): pg. 181-209. DOI. This article is (C) American Anthropological Association and permission has been granted for this version to appear in e-Publications@Marquette. American Anthropological Association does not grant permission for this article to be further copied/distributed or hosted elsewhere without the express permission from American Anthropological Association. 


\section{9/11: The Muslim Quarter under Siege}

For three consecutive nights beginning September 11, 2001 hundreds of angry white youth largely from the southwest suburbs, surrounded Bridgeview's Arab Muslim neighborhood, heading for the mosque.

Image unavailable due to third-party copyright restrictions. Please see definitive published version to view image:

http://dx.doi.org/10.1525/city.2005.17.2.181.

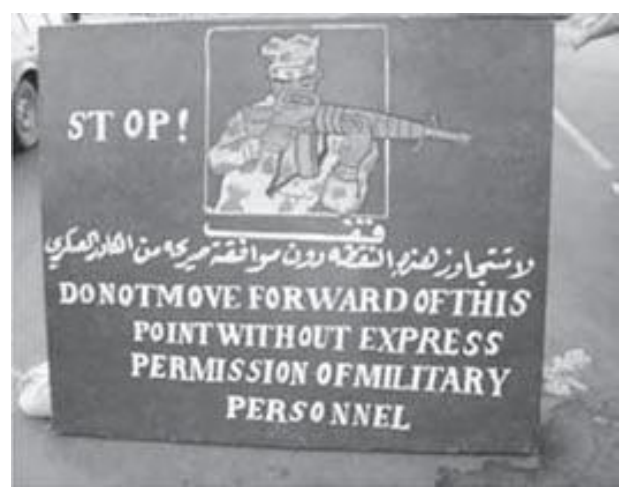

They were prevented from entering the area by more than 100 armed police and by checkpoints, a task made easier by the limited entrée to the area. Grateful for police protection, Arab and Muslim residents felt isolated and afraid. "I thought I left checkpoints in the Middle East" said one local resident.

\section{The Flag as a Prop}

Image unavailable due to third-party copyright restrictions. Please see definitive published version to view image:

http://dx.doi.org/10.1525/city.2005.17.2.181

The streets around the mosque and "Muslim Quarter" of Bridgeview after $9 / 11$.

\section{An American Institution the Mosque}

Image unavailable due to third-party copyright restrictions. Please see definitive published version to view image: http://dx.doi.org/10.1525/city.2005.17.2.181

Under police protection, mosque leaders hang the American flag.

All photos by Louise Cainkar, except as indicated. Photos may not be used without permission.

City and Society, Vol 17, No. 2 (December 2005): pg. 181-209. DOI. This article is @ American Anthropological Association and permission has been granted for this version to appear in e-Publications@Marquette. American Anthropological Association does not grant permission for this article to be further copied/distributed or hosted elsewhere without the express permission from American Anthropological Association. 
NOT THE PUBLISHED VERSION; this is the author's final, peer-reviewed manuscript. The published version may be accessed by following the link in the citation at the bottom of the page.

\section{Suburban Backlash}

Image unavailable due to third-party copyright restrictions. Please see definitive published version to view image:

http://dx.doi.org/10.1525/city.2005.17.2.181

Broad institutional presence did not about safety. Arab stores in Bridgeview and other southwest suburbs, identifiable by their Arabic script, were vandalized after the 9/11 attacks.

Image unavailable due to third-party copyright restrictions. Please see definitive published version to view image: http://dx.doi.org/10.1525/city.2005.17.2.181

Image unavailable due to third-party copyright restrictions. Please see definitive published version to view image:

http://dx.doi.org/10.1525/city.2005.17.2.181

\section{Defense and Solidarity}

Image unavailable due to third-party copyright restrictions. Please see definitive published version to view image: http://dx.doi.org/10.1525/city.2005.17.2.181

A non-Arab merchant placed signs on his lawn of this Palos Hills strip mall to protect the Arab business owners from attack.

Image unavailable due to third-party copyright restrictions. Please see definitive published version to view image:

http://dx.doi.org/10.1525/city.2005.17.2.181

Coalitions of Chicago-based civic organizations protested US government activities after 9/11 that targeted Arabs and Muslims, such as the Special Registration Program for Arab and Muslim men.

All photos by Louise Cainkar, except as indicated. Photos may not be used without permission.

City and Society, Vol 17, No. 2 (December 2005): pg. 181-209. DOI. This article is (C) American Anthropological Association and permission has been granted for this version to appear in e-Publications@Marquette. American Anthropological Association does not grant permission for this article to be further copied/distributed or hosted elsewhere without the express permission from American Anthropological Association. 
NOT THE PUBLISHED VERSION; this is the author's final, peer-reviewed manuscript. The published version may be accessed by following the link in the citation at the bottom of the page.

\section{Forging Alliances and Building Bridges}

Image unavailable due to third-party copyright restrictions. Please see definitive published version to view image: http://dx.doi.org/10.1525/city.2005.17.2.181

In an effort to fulfill the Islamic injunctions of benevolence and compassion for the poor, and to build relationships with Chicago area civic institutions, Muslims donated thousands of pounds of halal beef to the Chicago Food Depository, the single largest donation in the depository's history.

Image unavailable due to third-party copyright restrictions. Please see definitive published version to view image:

http://dx.doi.org/10.1525/city.2005.17.2.181

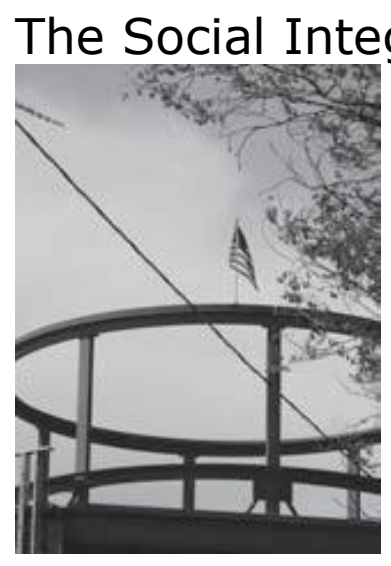

All photos by Louise Cainkar, except as indicated. Photos may not be used without permission.

City and Society, Vol 17, No. 2 (December 2005): pg. 181-209. DOI. This article is (C) American Anthropological Association and permission has been granted for this version to appear in e-Publications@Marquette. American Anthropological Association does not grant permission for this article to be further copied/distributed or hosted elsewhere without the express permission from American Anthropological Association. 


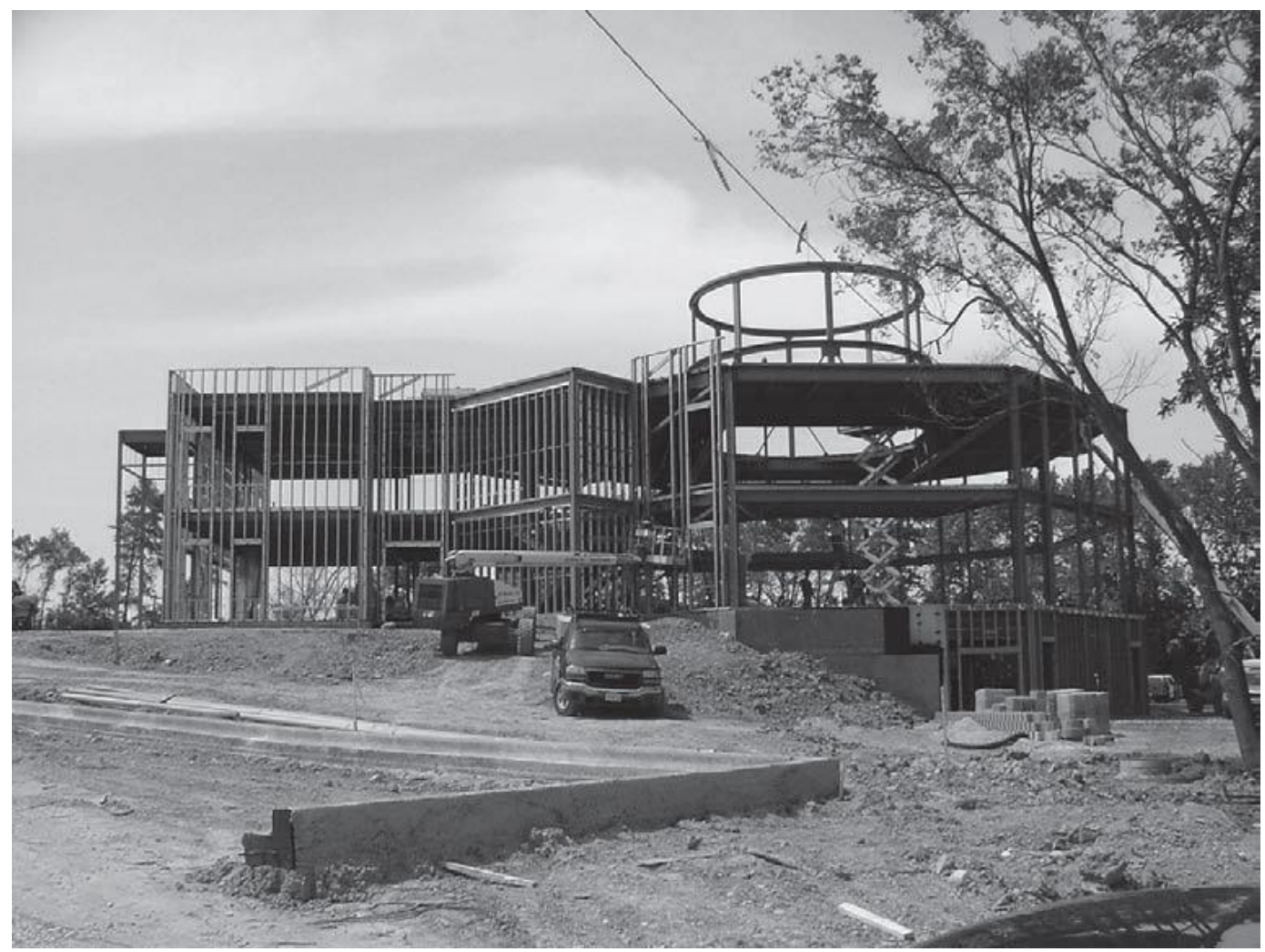

While prior attempts to build a new southwest suburban mosque had failed due to public protest, Muslims won approval in 2004 to construct a mosque in southwest suburban Orland Park. Expanded institutional relationships are facilitating the integration of Islam into the fabric of American society.

\section{Notes}

1. This photo essay includes data collected in a post-9/11 ethnographic study funded by the Russell Sage Foundation.

2. This belief led to public calls for Arabs and Muslims to denounce the 9/11 attacks, and to the response by many Arabs and Muslims that such a denunciation was tantamount to accepting group culpability.

3. Full study results are in the forthcoming book by the author (Cainkar n. d.).

4. Racialization was introduced by Omi and Winant 1994. I argue that racialist ideas can be hidden in other discourses, since open racism is not an effective tool to gain support for policies, and can cause a group to become experientially non-white. See

All photos by Louise Cainkar, except as indicated. Photos may not be used without permission.

City and Society, Vol 17, No. 2 (December 2005): pg. 181-209. DOI. This article is (C) American Anthropological Association and permission has been granted for this version to appear in e-Publications@Marquette. American Anthropological Association does not grant permission for this article to be further copied/distributed or hosted elsewhere without the express permission from American Anthropological Association. 
NOT THE PUBLISHED VERSION; this is the author's final, peer-reviewed manuscript. The published version may be accessed by following the link in the citation at the bottom of the page.

Jamal and Naber for a fuller discussion of the racialization of Arabs.

5. I consider legal rights (such as property ownership, voting, immigration, and naturalization), residential patterns, and employment experiences of Arab immigrants and their children as primary indicators of their marginal white social status.

6 . These themes assume prominence in scholarly research produced about the post-1960s Arab American experience, but do not characterize writing about the early Arab experience. Contact the author for sources.

7. The "racial liminality" of Arabs as well as historic Orientalism facilitated the capacity to project an "Arab, Muslim, Middle Eastern" phenotype, signifying the presence of racialist ideas hiding behind a discourse of cultural and civilizational differences. Arabs who did not match the phenotype had the (racial) option to be white.

8. An institutionally complete community contains a "spatially clustered network of businesses owned by members of the same minority [immigrant] group" (Portes 1995:27) that serves a wide range of needs specific to the community. Portes' description of institutionally complete Cuban Miami is quite different from the southwest suburban Arab community, because the latter contains no manufacturing and offers limited job opportunities.

9. Data are from ethnographic field notes. See references for published reports.

10. I cover this topic extensively in Cainkar 2004.

11. Secular Arab parties were also critical of these policies.

\section{References}

Cainkar, Louise. 1999. The Deteriorating Ethnic Safety Net Among Arabs in Chicago. In Arabs in America: Building a New Future. Michael Suleiman, ed. Pp. 192-206. Philadelphia: Temple University Press.

Cainkar, Louise. 2004. Islamic Revival Among Second Generation Arab-American Muslims: The American Experience and Globalization Intersect. Bulletin of the Royal Institute for InterFaith Studies 6(2):99-120.

All photos by Louise Cainkar, except as indicated. Photos may not be used without permission.

City and Society, Vol 17, No. 2 (December 2005): pg. 181-209. DOI. This article is @ American Anthropological Association and permission has been granted for this version to appear in e-Publications@Marquette. American Anthropological Association does not grant permission for this article to be further copied/distributed or hosted elsewhere without the express permission from American Anthropological Association. 
NOT THE PUBLISHED VERSION; this is the author's final, peer-reviewed manuscript. The published version may be accessed by following the link in the citation at the bottom of the page.

Cainkar, Louise. N.d. Homeland Insecurity: The Arab/Muslim American Experience after 9/11. New York: Russell Sage Press. Working title.

Huntington, Samuel. 1996. The Clash of Civilizations and the Remaking of World Order. New York: Simon and Schuster.

Jamal, Amaney and Nadine Naber, eds. N.d. From Invisible Citizens to Visible Subjects: "Race" and Arab Americans Before and after September 11th. Syracuse: Syracuse University Press.

Omi, Michael and Howard Winant. 1994. Racial Formation in the United States: From the 1960s to the 1990s. New York: Routledge.

Portes, Alejandro, ed. 1995. The Economic Sociology of Immigration. New York: Russell Sage. 